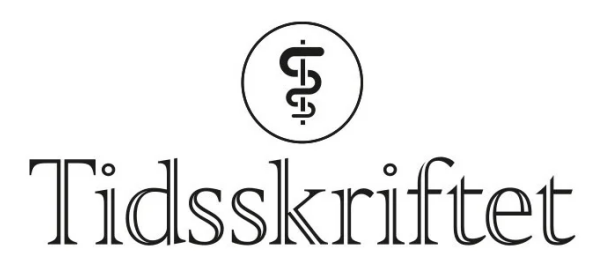

DEN NORSKE LEGEFORENING

\title{
A. Bjerring og medarbeiderne svarer
}

\author{
KOMMENTAR \\ ANDERS WOLD BJERRING \\ anders81@gmail.com \\ Anders Wold Bjerring er lege i spesialisering i kardiologi.
}

THOR EDVARDSEN

SEBASTIAN IMRE SARVARI

ERIK EKKER SOLBERG

Forfatterne har ikke oppgitt noen interessekonflikter.

Takk til Kjetil Retterstøl for et aktuelt og godt spørsmål.

Myokarditt er årsak til 5- 15 \% av plutselig hjertedød hos atleter, men det er usikkerhet knyttet til tallene og de varierer med alder (1). Koblingen mellom myokarditt og mRNAvaksinene mot Covid-19 er et aktuelt tema. Både amerikanske og israelske helsemyndigheter har slått fast at det er en sannsynlig kobling. Dette synet støttes i hovedsak også av WHO (ㅁ).

Dersom det er en reell kausal sammenheng, er det primært mistanke om en hypersensitivtetsmyokarditt, en type eosinofil myokarditt. I en case-serie fra det amerikanske forsvaret, gikk det i snitt 50 timer fra vaksinasjon til symptomdebut (3). Over $90 \%$ hadde mildt sykdomsforløp.

Det er altså betydelig usikkerhet rundt tallene, en kausal sammenheng er sannsynlig, men ikke sikker, insidensen er lav og forløpene milde. Det finnes dessuten studier som viser at personer som trener regelmessig har bedre effekt av vaksiner (4). . Det finnes per nå ikke særskilte råd om opphold $\mathrm{i}$ trening ifm. vaksinering. Sammenhengen mellom myokarditt og mRNA-vaksinene har imidlertid medført en grad av usikkerhet knyttet til idrettsaktiviteter. Derfor kan det være et godt råd å anbefale at atleter unngår hard trening i anslagsvis tre døgn etter vaksinasjon, særlig etter dose to. Om man da ikke har fătt symptomer suspekt på hjertesykdom og ikke lenger har noen av de vanlige bivirkningene av vaksinen, kan man gjenoppta trening som normalt. Dette er ikke offisielle anbefalinger og rådene er basert på sparsomt med data. Vaksinen igangsetter en immunrespons og det er generelt ikke tilrådelig og ofte kontraproduktivt for formutvikling å trene hardt under pågående inflammasjon/infeksjon. 
Vedrørende Christian Eriksen, så har det versert sprikende informasjon om hvorvidt han var nylig vaksinert eller ikke, men en faktasjekk utført av USA Today har slått fast at han var uvaksinert (5).

\section{LITTERATUR}

1. Eichhorn C, Bière L, Schnell F et al. Myocarditis in athletes is a challenge: Diagnosis, risk stratification, and uncertainties. JACC Cardiovasc Imaging 2020; 13: 494-507. [PubMed][CrossRef]

2. WHO. COVID-19 subcommittee of the WHO Global Advisory Committee on Vaccine Safety (GACVS): updated guidance regarding myocarditis and pericarditis reported with COVID-19 mRNA vaccines 2021. https://www.who.int/news/item/o9-07-2021-gacvs-guidance-myocarditis-pericarditiscovid-19-mrna-vaccines Lest 16.7.2021.

3. Montgomery J, Ryan M, Engler R et al. Myocarditis following immunization with mRNA COVID-19 vaccines in members of the US military. JAMA Cardiol 2021 doi: 10.1001/jamacardio.2021.2833. [PubMed][CrossRef]

4. Chastin SFM, Abaraogu U, Bourgois JG et al. Effects of regular physical activity on the immune system, vaccination and risk of community-acquired infectious disease in the general population: Systematic review and meta-analysis. Sports Med 2021; 51: 1673-86. [PubMed][CrossRef]

5. USA Today. Fact Check: Christian Eriksen didn't receive the Covid-19 vaccine before collapsing. https://eu.usatoday.com/story/news/factcheck/2021/o6/20/fact-check-christian-eriksendidnt-receive-covid-19-vaccine/7713275002/ Lest 16.7.2021.

Publisert: 6. september 2021. Tidsskr Nor Legeforen. DOI: 10.4045/tidsskr.21.0583

(c) Tidsskrift for Den norske legeforening 2023. Lastet ned fra tidsskriftet.no 26. april 2023. 